\title{
A Study Of Green Hr Practices Andit'seffective Of Implemention In Five Star Hotels In Jordan
}

\author{
Majed Massad Suliman Al Rawashdeh ${ }^{1}$, Amgad S. D. Khaled ${ }^{2}$ \\ Dep. Of Management Information System, Al Rowad University, Taiz, Yemen \\ 2amgad2011alprince@gmail.com
}

\begin{abstract}
Green HRM is the integration of corporate environmental management into HRM. Typical green activities contain online interviews and training, green payroll, electronic signatures to avoid wasting paper, and using porcelain cups for tea. The present research has been undertaken to study the green HR practices in five star hotels. For the purpose of the study, a sample of 151employees has been selected for the study. Data have been collected through self administered questionnaires designed on a five point Likert scale. Independent sample t-test has been used as the statistical tool to measure the difference in green HR practicesin hotel of Jordan. The analysis of the data revealed that significant differencedo not exists in green HR practicesin Movenpick hotel and Intercontinental hotel
\end{abstract}

Keywords

Green HR, employees, Hotels, Movenpick Hotel, Intercontinental Hotel, t-test

Article Received: 10 August 2020, Revised: 25 October 2020, Accepted: 18 November 2020

\section{Introduction}

The global tourism industry has continued to expand every year since 1950. Global tourism arrivals in Asia Pacific range from $3 \%$ to $4 \%$ and from $4 \%$ to $5 \%$ in 2015 (UNTWO, 2015). This change is expected to increase 4 percent annually, contributing to high demand in rooms over the next 10 years (Hotel Investment Outlook, 2017). As tourism grows, hotels also have the same phenomenon as hotels worldwide with over 300,000 accommodation and facilities, partly open to foreign and national visitors (Bohdanowicz, Simanic, \&Martinac, 2005). Asia Pacific Hotels reported revenues of $\$ 8.5$ billion in 2016 and Asia Pacific generated volumes of $\$ 8.5$ billion in 2017 . (Investment Hotel Forecast, 2017).

Many hotels face both internal and external pressure and have to pay attention to environmental protection through the provision of environmentally friendly hotel facilities, which are not harmful to the environment and safer for clients. These stresses are greater towards the hotel industry, which directly contributes to environmental problems such as water, power and waste (Graci\&Kuehnel, 2011). As Gössling et al. (2005) said, the hotel industry emits an average of $20,6 \mathrm{~kg}$ per night of carbon dioxide and uses 130 megas of energy per bed per night in the hotel. Consequently, annual energy consumption has risen in the hotel industry to USD 3.7 billion (Bruns-smith, Choy, Chong, \& Verma, 2015). In addition, the hotel industry generates at least $1 \mathrm{~kg}$ per day per customer and uses at a standard hotel 218 gallons per day per room (Bohdanowicz, 2005); (Bruns-smith et al., 2015). Because of the many environmental concerns in the hospitality industry, the intensity is growing to adequately respond to environmental problems (Erdogan \& Baris, 2007).

The ability of a hotel to change direction and strategically reconfigure is vital to the success of environmental efficiency and the ever growing rivalry. In other words, we recommend that hotels follow methods for green capital management (green HRM). Recent empirical evidence reinforces the claim that Green HRM operations yield good results (e.g., Daily, Bishop, \&Massoud, 2012; Guerci, Longoni, \&Luzzini, 2016; Jabbar \& Abid, 2014). It is therefore not surprising that Green HRM activities in academic and professional literature are growing increasingly relevant. (Khaled, A.S. et al., 2019)

The HR role plays an important role in determining the activities to sustain and execute an ongoing process across all corporate dimensions at all levels of an organisation (Cohen, Taylor \& Muller-Camen, 2012). Green HRM is the safest sustainability solution and green HRM is a fundamental mechanism for tracking the company's environmental impacts (Sudin, 2011). A. A and Sheopuri. A and Sheopuri. A and Sheopuri. A and Sheopuri. Sheopuri (2015) states that green HRM practises include environmentally sustainable $\mathrm{HR}$ activities that result in reduced costs, improved efficiency and greater retention and participation of staff, helping companies to minimise carbon footprints.

Green HRM practises must also be recognised that accelerate the hotel industry's commitment to environmental quality. The aim of this article is to provide empirical proof of Green HRM activities in hotels.

\section{Green Human Resources Management (GHRM)}

Corporate environmental management incorporation into HRM is defined as green HRM. Most citizens, including experts and scholars, are unfamiliar. The word 'eco HR' also refers to the contribution of HR policies and activities in the wider environmental corporate agenda of the sustainable use of natural resources. Green Human Resources Management (GHRM) can be characterised as a collection of policies, practise, and processes that encourage the green actions of an employee of a company to build a workplace and an organisation as a whole, environmentally responsive, resource efficient, and socially responsible. It includes the 
activity of human resources to increase workers' awareness and contribution to sustainability issues. Green HR is the contribution of the strategies and actions of people management towards the aims of the company. (Khaled A.S. et al., 2020)

Typical Green companies include green production and disposal systems, teleconferences and interactive interviews, online training, electronic filing, green payrolls, corporate transport, car-sharing or hybrid / electric vehicles, job walking or cycling. Porcelain mugs and glasses are for tea and coffee. The benefits of GHRM are many: enhanced corporate moral, employee engagement and reduction of labour turnover, increased public profile, competitive advantage, increased consumer/customer trust, employee loyalty and awareness of brands, position as a preferred employer, increased productivity of employees, performance, encouragement and retention of employees. (Dr. Khaled et. al., 2021)

Green Human Resource Management is a process of ensuring that the management system practicing in an organization is ecologically balanced and environmentally affable. Today's organizations are paying more attention on implementation of green HRM as it can create a positive image \& bring competitive advantages for the organization which will help the organization to survive in long run successfully. It can also enhance the capability of an organization to reach its missions \& visions in effective $\&$ efficient manner.

\section{Literature Review}

Over the last two decades, sustainability in the hospitality industry has gained momentum. In the field of sustainability, the hotel industry has made significant efforts. Sustainable practises in the hotel industry include productive water and energy use, waste management and local procurement. There was also sustainability among customers who were interested in 'green' hotels. Moreover, quick advanced technologies enable hospitality to increase productivity and cut operational costs such as solar energy for power generation, computerised water systems and sensor-sensitive lighting and heating systems that minimise impacts on the environment. Jordan initiated the National Tourism Strategy (NTS) in 2004. (2004-2010). This is the first comprehensive tourism initiative to improve the industry's sustainable potential. The strategy was developed in partnership with public and private tourism actors to coordinate and direct tourism and hospitality growth. (Amgad S. et. al., 2020)

In executing this strategy, Jordan has made it possible to boost its status as its preferred destination for tourists and investors. The second NTS 2011/2015 explained how the Tourism \& Hospitality Sector will achieve long-term sustainability targets, by exploring the three pillars of social, economic and environmental sustainable development. Hotels have large amounts of waste and excessive use of water. Hotels are also responsible for adverse resource depletion reactions. Hotels work to increase their performance, to protect water and energy through sustainable environmental practises and to minimise waste. Hotels are also committed to engaging stakeholders in achieving sustainable environmental quality. The hotel industry in Jordan is seen as an important element in the economy, but there has been little research into sustainable practises in environmental and business issues. (Khaled A.S. et al., 2020)

The study's main findings are $75 \%$ backed by good environmental performance with green recruiting, green training, development and green pay. This study shows that the organisation can use green HRM practises to improve the environmental productivity of its workers (Paillé et al. 2013). Moreover, improved environmental performance requires HRM practises that help to completely incorporate and maintain environmental policies and activities in organisations (Jabbour\& Santos, 2008).

There is a lack of knowledge concerning environmental awareness and concern for the hotel industry in Malaysia and how the daily practise of hotels is connected with environmental efficiency (Erdogan \& Baris, 2007). This result, therefore. Green recruiting and selection have a beneficial influence on environmental performance and contribute to an important strategic convergence of the green recruitment hotel industry as it enables employers to lead rivals and helps them to attract and retain applicants after guidance and training (Ahmad \& Nisar, 2015). The hotel industry must also attract green applicants to improve environmental efficiency. The hotel sector must then invest in people who are already environmentally conscious and who are used for environmental protection, for example waste management, recycling and ISO 14001 certification. This helps hotels to achieve environmental performance (Ahmad \& Nisar, 2015; Amgad S. et. al., 2020).

Competition, ecosystem performance, social welfare and financial success should be used by companies as green HRM methods (Bansal \& Roth, 2000). This study therefore found that green training is positively correlated with environmental efficiency. Jabbour (2013) validated this result by preparing environmentally or green for all good environmental performance practises. Aragón-Correa et al. (2015) have found that greening is an effective activity for sustainable environmental development, enhanced environmental capability and sensitiveness and improved environmental outcomes (Wagner, 2013). The hotel industry must provide its workers with environmental training in order to make environmental success part of the organization's culture to improve their environmental qualifications and understanding (Bansal \& Roth, 2000).

This study also shows that green compensation has a significant environmental impact. According to Ahmad and Nisar (2015), rewards would boost the awareness of the workers and motivate them to do whatever they can to achieve the goals of the company. Furthermore, businesses can encourage environmentally sustainable practises and improvements in facilities and procedures through an effective compensation scheme (Govindarajulu\& Daily, 2004).

Working satisfaction

Employment satisfaction is the content and dedication of workers to their jobs and performance (Kalleberg, 1997). Satisfied staff are more prepared and willing to actively participate in green initiatives. Satisfied workers feel responsible for the environment and commit themselves to green initiatives and increase their environmental performance (Ahmad, 2015). Satisfied workers are less 
satisfied with their jobs than they are engaged in their assignments. This means that job satisfaction forces employees to enforce green policies and reduce environmental harm (Fernandez, Junquera\&Ordiz, 2003).

\section{Green benefits and compensation}

In the area of green work, green awards are fulfilled and lead to environmental efficiency (Lawler at all, 2008). It is briefly said that green income contributes to the highest level of work satisfaction, which substantially increases environmental performance (Lawler \& Porter, 2008). Environmental benefits and promotions have a huge effect on employee satisfaction (Renwick at all, 2013). The use of environmental benefits and appreciation has a positive influence on the willingness of workers to evaluate green initiatives (Ramus, 2001). Rewards boost incentives and make workers accountable (Daily and Huang, 2001). The recompense services can also be used periodically to facilitate the required behaviours of workers in order to benefit the organisation and its employees. (Huang and Daily, 2001). 2001). 2001. 2001.

\section{Environmental preparation}

GHRM preparation allows GHRM workers to gather waste knowledge in order to improve their environmental skills and eco-literacy (Roy and Therin 2008). Planning will allow continuous changes (Cook and Seith, 1992; CurKovic, 1998). For employees to participate in green initiatives, environmental training is necessary (Cook and Seith, 1992). Training leads to new learning, which eventually helps staff to produce better results (Naong, 2014). Training can be used to train, improve and inspire staff to find positive results on workplace challenges and changes (Struwig\& Smith, 2000).

A research titled 'A study on green HR activities and its effect on environmental performance: a review' showed that higher levels of employee satisfaction are dependent on environmental awareness. Research has shown that the most popular IT identification is energy saving, online leave registrations, a plastic free zone, E HRM, video conferencing and electro-recording. The authors suggested that management staff should be properly trained to practise green HR to train employees. Disciplinary action should be taken to punish staff who violate legislation on green practise. Furthermore, financial incentives must be offered to encourage employees' green behaviour. Researchers say managers should include financial incentives to promote green conduct and train workers to achieve higher standards of efficiency. The authors argue that the research project helped managers boost their operational performance and achieve their goals. The study was conducted in Pakistan with 354 workers from 13 production organisations. The results have shown substantial impacts in all GHRM dimensions on sustainability. Industries have also been found to have skipped the preparation and induction programme for workers solely aimed at delivering the right greening awareness and skills. Oyewale (2019) analysed the green management and its impact on Dangote Nigeria staff on the Nigerian manufacturing industry's sustainable competitive edge. Green recruitment, green training and growth methods and a green rewards scheme have been shown to have a positive and powerful impact on the competitive edge of green economies. The study showed that most respondents understand the concept of green HRM and the effects of green HR practises among different types of banks are significant. The results show that Green WLB and Green Work are important for the satisfaction of employees. Green life, however, is another area of GWLB that is green every day.

\section{Objective of the study}

The objective of the study is to investigate the differences in green HR practices between Movenpick hotel and Intercontinental hotel.

\section{Hypotheses Of The Study}

$\mathrm{Ho}_{1}$ : There is no significant difference in green $\mathrm{HR}$ practices between Movenpick hotel and Intercontinental hotel.

$\mathrm{Ha}_{1}$ : There is a significant difference in green HR practices between Movenpick hotel and Intercontinental hotel.

\section{Research Methodology}

The study's target population consists of all workers at fivestar hotels in Jordan. The sample size of the study was 151.The basic data was collected by circulating online questionnaires. Simple random sampling was used to collect data. A total of 200 questionnaires were sent to the workers employed in the selected hotels via e-mail. Because of errors and missing details 49 questionnaires were rejected and 151 were accepted. In addition, secondary knowledge was gathered through books, magazines, posts, theses and the internet. The data collection period is from October 2020 to December 2020. The collected data was analysed in the SPSS 20 version by cronbach alpha, average, SD and independent sample t test.

Table 1: Questionnaires distributed, rejected, and accepted

\begin{tabular}{|l|l|l|l|l|}
\hline \multirow{2}{*}{$\begin{array}{l}\text { N } \\
\text { o. }\end{array}$} & \multirow{2}{*}{ Hotels } & \multicolumn{3}{|l|}{ Questionnaires } \\
\cline { 3 - 5 } & $\begin{array}{l}\text { Distrib } \\
\text { uted }\end{array}$ & $\begin{array}{l}\text { Reje } \\
\text { cted }\end{array}$ & $\begin{array}{l}\text { Accep } \\
\text { ted }\end{array}$ \\
\hline 1 & $\begin{array}{l}\text { Movenpick } \\
\text { Hotel }\end{array}$ & 100 & 29 & 71 \\
\hline 2 & $\begin{array}{l}\text { Intercontine } \\
\text { ntal Hotel }\end{array}$ & 100 & 20 & 80 \\
\hline & Total & 200 & 49 & 151 \\
\hline
\end{tabular}

Source: Primary Data

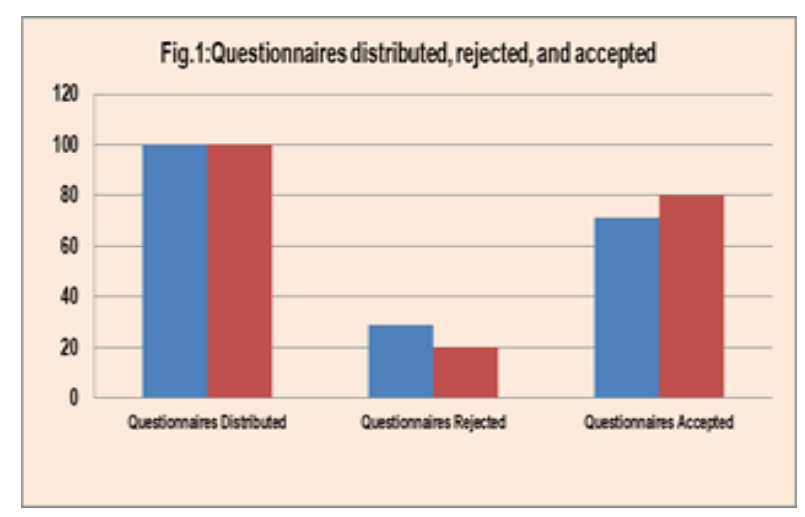




\section{Analysis}

\section{Demographics}

In addition $\mathrm{n}$ to the scales mentioned above, the final instrument also consisted of questions related to demographics. Demographic facts were collected through multiple choice questions. The questions were regarding type of account held, gender, nationality, age of respondents, marital status, occupation, education, monthly income, nature of bank, length of relation and reason for choosing.

Table 2: Demographic profile

\begin{tabular}{|c|c|c|c|c|c|}
\hline $\begin{array}{l}\text { Responde } \\
\text { nts Profile }\end{array}$ & Items & $\begin{array}{l}\text { Perce } \\
\text { nt }\end{array}$ & $\begin{array}{l}\text { Responde } \\
\text { nts Profile }\end{array}$ & Items & $\begin{array}{l}\text { Perce } \\
\text { nt }\end{array}$ \\
\hline \multirow[b]{2}{*}{ Gender } & Male & 86.5 & \multirow{5}{*}{ Education } & $\begin{array}{l}\text { High } \\
\text { School }\end{array}$ & 3 \\
\hline & $\begin{array}{l}\text { Femal } \\
e\end{array}$ & 13.5 & & $\begin{array}{l}\text { Diplom } \\
a\end{array}$ & 8.6 \\
\hline \multirow{5}{*}{ Age } & $\begin{array}{l}20-29 \\
\text { years }\end{array}$ & 8.6 & & $\begin{array}{l}\text { Gradua } \\
\text { te }\end{array}$ & 23.7 \\
\hline & $\begin{array}{l}30-39 \\
\text { years }\end{array}$ & 25.4 & & $\begin{array}{l}\text { Post } \\
\text { Gradua } \\
\text { te }\end{array}$ & 37.5 \\
\hline & $\begin{array}{l}40-49 \\
\text { years }\end{array}$ & 40.5 & & Others & 27.2 \\
\hline & $\begin{array}{l}50-59 \\
\text { years }\end{array}$ & 14.2 & \multirow{4}{*}{$\begin{array}{l}\text { Monthly } \\
\text { Income }\end{array}$} & $\begin{array}{l}\text { Below } \\
400\end{array}$ & 26.3 \\
\hline & $\begin{array}{l}60 \text { and } \\
\text { above }\end{array}$ & 11.2 & & $\begin{array}{l}300- \\
400\end{array}$ & 40.5 \\
\hline \multirow{2}{*}{$\begin{array}{l}\text { Marital } \\
\text { Status }\end{array}$} & Single & 10.3 & & $\begin{array}{l}400- \\
500\end{array}$ & 23.7 \\
\hline & $\begin{array}{l}\text { Marri } \\
\text { ed }\end{array}$ & 89.7 & & $\begin{array}{l}\text { Above } \\
500\end{array}$ & 9.5 \\
\hline
\end{tabular}

\section{Demographic Highlights}

- $\quad$ Majority of the respondents were male. (86.5\%)

- Majority of the respondents were from the age group of 40-49 years. (40.5\%)

- $\quad 89.7 \%$ of the respondents were married.

- Almost equal number of the respondents was working in government sector or they were into some other profession. (33.6\% and $33.2 \%$ )

- Majority of the respondent had monthly income between $300-400$

\section{Reliability Analysis}

Cronbach alpha has been applied to test the reliability of all statements. Table 3 highlights the reliability of all statements used in the study. The values of cronbach alpha on the first and third statement are 0.784 and 0.854 respectively. The highest value of alpha has been recorded on second statement. No statement has shown the value less than 0.6 which cleared the way for testing hypotheses.
Table 3: Reliability Analysis

\begin{tabular}{|c|c|c|}
\hline No & Statements & $\begin{array}{l}\text { Cronbach } \\
\text { alpha }\end{array}$ \\
\hline 1 & $\begin{array}{l}\text { The employees are aware about Green } \\
\text { HRM concept, strategy and initiatives. }\end{array}$ & 0.784 \\
\hline 2 & $\begin{array}{l}\text { The hotel has generated online leave } \\
\text { application and electronic slip } \\
\text { generation system. }\end{array}$ & 0.915 \\
\hline 3 & $\begin{array}{l}\text { The hotel uses recycled paper in the } \\
\text { office and puts record electronically. }\end{array}$ & 0.854 \\
\hline 4 & The hotel has plastic free zone. & 0.701 \\
\hline 5 & $\begin{array}{l}\text { The hotel encourages conferences, } \\
\text { seminar on } \\
\text { sustainability. }\end{array}$ & 0.697 \\
\hline 6 & $\begin{array}{l}\text { The hotel conducts interview and } \\
\text { joining formalities in paperless form. }\end{array}$ & 0.662 \\
\hline 7 & $\begin{array}{l}\text { The hotel provides proper training to } \\
\text { the employees before implementation } \\
\text { of green initiative. }\end{array}$ & 0.714 \\
\hline 8 & $\begin{array}{l}\text { The hotel conducts paperless training } \\
\text { session to generate awareness about } \\
\text { current environmental issues. }\end{array}$ & 0.748 \\
\hline 9 & $\begin{array}{l}\text { The hotel provides financial and non } \\
\text { financial awards for green performance. }\end{array}$ & 0.833 \\
\hline 10 & $\begin{array}{l}\text { The hotel takes disciplinary action for } \\
\text { the employees who violate rules of } \\
\text { green practices. }\end{array}$ & 0.783 \\
\hline
\end{tabular}

Source: Output of SPSS_20

\section{Confirmatory Factor Analysis}

Variables have been summarized in the exploratory factor analysis (EFA) output factors, while the findings have been interpreted in terms of factor loading, cross loading and factor independence. In order to overcome this limitation as established by the EFA, Lee (2008) suggested carrying out confirmatory factor analysis. The Confirmatory Factor Analysis (CFA) measurement model comprises all variables retained following the analysis of exploratory factor and reliability measures. Confirmatory factor analysis (CFA) is a method of factor analysis in which some hypotheses of latent variables are checked and organized (Field, 2009). CFA is a theoretical technique that shows that theory guides the relationship of the variables observed (Suhr, 2006). CFA is a way to validate or deny a hypothesis. A hypothesised model is used to measure population covariance relative to the observed covariance. The measuring model is used to examine covariation and connections between latent buildings. CFA is a versatile method to analyse the structural logic (Reise, Waller \&Comrey, 2000; Floyd \&Widaman, 1995).

Table4. Model fit

\begin{tabular}{|l|l|l|l|}
\hline Fit Index & $\begin{array}{l}\text { Recommended } \\
\text { Value }\end{array}$ & Source & Value \\
\hline $\begin{array}{l}\text { Chi- } \\
\text { Square/ df }\end{array}$ & $<3.0$ & $\begin{array}{l}\text { Kline, } \\
2004\end{array}$ & 2.437 \\
\hline GFI & $>.80$ & & 1.00 \\
\hline AGFI & $>.80$ & & .409 \\
\hline RMSEA & $<.07$ & & .122 \\
\hline CFI & $>.80$ & & 1.00 \\
\hline RMR & $<.01$ & & .197 \\
\hline
\end{tabular}




\section{Independent sample t-test}

Independent sample $\mathrm{t}$ test has been applied to test the differences in green HR practices in Movenpick hotel and Intercontinental hotel. Table 5 highlights the results of Independent sample $\mathrm{t}$ test in abridged form on the first statement, the mean values in both the hotels are less than 3 which shows that majority of the employees are unaware about the concept of green HRM. Besides, the value of $t$ has been -1.587 and the significant value corresponding to it is 0.857 ( $\mathrm{P}>0.05)$ which shows that no significant differences found in the awareness of Green HRM concept between employees of both hotels. On the second statement, the mean values in both the banks are more than 4 which show that both the hotels have generated online leave application and electronic slip generation system. Moreover, the value of $t$ has been 3.547 and the significant value corresponding to it is 0.665 which shows that significant differences do not exists between the hotels.

On the third statement, the mean values in both the banks are less than 3 which show that the banks uses recycled paper in the office and puts record electronically but to a minimum level. Besides, the value of $t$ has been -4.008 and the significant value corresponding to it is 0.306 which shows that no significant differences found in the banks under study on the use of recycled paper and putting record electronically. On the fifth statement, the mean values in both the banks are around 3 which show that the bank encourages conferences, seminar on environmental sustainability. Besides, the value of $\mathrm{t}$ has been -4.008 and the significant value corresponding to it is 0.306 which shows that no significant differences found in encouraging conferences, seminar on environmental sustainability.
On the sixth statement, the mean values of both the hotels are more than 4 and the $\mathrm{p}$ value is $0.407(\mathrm{P}>0.05)$. It means significant differences do not found about conducting interview and joining formalities in paperless form. On the seventh statement, the mean values of Movenpick hotel and Intercontinental hotel are 1.952 and 2.041 respectively. Both the values are less than 3 which show that proper training has not been provided to the employees before implementation of green initiative in their hotels. Moreover, the $\mathrm{p}$ value on this statement is $0.574(\mathrm{P}>0.05)$. It means significant differences do not found regarding training to the employeesunder the hotels.

On the eighth statement, the mean values of both the hotels are less than 2 and the significant value on this statement $0.195(\mathrm{P}>0.05)$. It means that there is no significant difference in conducting paperless training session to generate awareness about current environmental issues between the hotels. On the ninth statement, the mean values of Movenpick hotel and Intercontinental hotel are 3.854 and 3.609 respectively. Both the values are more than 3 which show that the bank provides financial and non-financial awards for green performance. The significant value on this statement is $0.273(\mathrm{P}>0.05)$. It means that there is no significant difference is distribution of financial and non financial awards.

The mean values of Movenpick hotel and Intercontinental hotel are 1.043 and 1.008 respectively on the tenth statement. The significant value on this statement is 0.459 $(\mathrm{P}>0.05)$. It means that significant difference do not exist between hotels regarding disciplinary action against the employees for violating rules of green practices. Finally, after the results of $t$ test, it can be said that there is no significant difference in green HR practices between Movenpick hotel and Intercontinental hotel.

Table 5: Results of Independent sample t test in Abridged Form

\begin{tabular}{|c|c|c|c|c|c|c|c|}
\hline & STATEMENTS & Hotels & $\mathbf{N}$ & Mean & SD & $\mathbf{T}$ & Sig. \\
\hline \multirow[t]{2}{*}{1} & \multirow{2}{*}{$\begin{array}{l}\text { The employees are aware about } \\
\text { green HRM concept, strategy and } \\
\text { initiatives. }\end{array}$} & Movenpick & 71 & 2.045 & \multirow[b]{2}{*}{0.997} & \multirow[b]{2}{*}{$\overline{1}-587$} & \multirow[b]{2}{*}{0.857} \\
\hline & & intercontinental & 80 & 2.294 & & & \\
\hline \multirow[t]{2}{*}{2} & \multirow{2}{*}{$\begin{array}{l}\text { The hotel has generated online } \\
\text { leave application and electronic } \\
\text { slip generation system. }\end{array}$} & Movenpick & 71 & 4.564 & \multirow[b]{2}{*}{0.873} & \multirow[b]{2}{*}{3.547} & \multirow[b]{2}{*}{0.665} \\
\hline & & intercontinental & 80 & 4.397 & & & \\
\hline \multirow[t]{2}{*}{3} & \multirow{2}{*}{$\begin{array}{l}\text { The hotel uses recycled paper in } \\
\text { the office and puts record } \\
\text { electronically. }\end{array}$} & Movenpick & 71 & 2.541 & \multirow[b]{2}{*}{0.774} & \multirow[b]{2}{*}{4.008} & \multirow[b]{2}{*}{0.306} \\
\hline & & intercontinental & 80 & 2.007 & & & \\
\hline \multirow[t]{2}{*}{4} & \multirow[t]{2}{*}{ The hotel has plastic free zone. } & Movenpick & 71 & 2.662 & \multirow[b]{2}{*}{0.905} & \multirow[b]{2}{*}{6.628} & \multirow[b]{2}{*}{0.758} \\
\hline & & intercontimental & 80 & 2.485 & & & \\
\hline \multirow[t]{2}{*}{5} & \multirow{2}{*}{$\begin{array}{l}\text { The hotel encourages } \\
\text { conferences, seminar on } \\
\text { environmental sustainability. }\end{array}$} & Movenpick & 71 & 3.263 & \multirow[b]{2}{*}{0.775} & \multirow[b]{2}{*}{$\overline{1} .559$} & \multirow[b]{2}{*}{0.904} \\
\hline & & intercontinental & 80 & 3.059 & & & \\
\hline \multirow[t]{2}{*}{6} & \multirow{2}{*}{$\begin{array}{l}\text { The hotel conducts interview and } \\
\text { joining formalities in paperless } \\
\text { form. }\end{array}$} & Movenpick & 71 & 4.478 & \multirow[b]{2}{*}{0.652} & \multirow[b]{2}{*}{8.984} & \multirow[b]{2}{*}{0.407} \\
\hline & & intercontinental & 80 & 4.001 & & & \\
\hline \multirow[t]{2}{*}{7} & \multirow{2}{*}{$\begin{array}{l}\text { The hotel provides proper training } \\
\text { to the employees before } \\
\text { implementation of green } \\
\text { initiative. }\end{array}$} & movenpick & 71 & 1.952 & \multirow[b]{2}{*}{1.003} & \multirow[b]{2}{*}{$\overline{3} .132$} & \multirow[b]{2}{*}{0.574} \\
\hline & & intercontinental & 80 & 2.041 & & & \\
\hline 8 & The hotel conducts paperless & movenpick & 71 & 1.557 & & & \\
\hline & $\begin{array}{l}\text { training session to generate } \\
\text { awareness about current } \\
\text { environmental issues. }\end{array}$ & intercontinental & 80 & 1.365 & 0.946 & 5.557 & 0.195 \\
\hline 9 & The hotel provides financial and & movenpick & 71 & 3.854 & & & \\
\hline & $\begin{array}{l}\text { non financial awards for green } \\
\text { performance. }\end{array}$ & intercontinental & 80 & 3.609 & 0.822 & 9.541 & 0.273 \\
\hline 10 & The hotel takes disciplinary & movenpick & 71 & 1.043 & 0.590 & 2082 & 0.450 \\
\hline & violate rules of green practices & intercontinental & 80 & 1.008 & 0.199 & & 0.458 \\
\hline
\end{tabular}

Source: Output of SPSS_20 


\section{Hypothesis testing by Regression Analysis}

1. Table shows the result of regression analysis use to determine the impact of Recruitment on overall satisfaction. The result shows the impact is positive (coefficient $=0.456$ ) a. H01: there is significance impact of Recruitment on satisfaction, therefore, $\mathrm{H} 01$ is not acceptable.

2. Table shows the result of regression analysis use to determine the impact of Selection on overall satisfaction The result shows the impact is positive (coefficient $=0.041$ ). Further, this impact is statistically not significant. As sig $=0.318>0.05$. Therefore, H02 is acceptable.

a. $\mathrm{H} 02$ : there is significance impact of selection on satisfaction

3. The table shows that there is a positive impact (0.742).

a. H03: there is significant impact of retrenchment on satisfaction, The hypothesis is accepted thus there is an impact.

Table6: Regression Analysis for checking the impact

\begin{tabular}{|c|c|c|c|c|c|}
\hline $\begin{array}{l}\text { S.N } \\
\text { o }\end{array}$ & $\begin{array}{l}\text { Independe } \\
\text { nt variable }\end{array}$ & $\begin{array}{l}\text { Depende } \\
\text { nt } \\
\text { variable }\end{array}$ & $\begin{array}{l}\text { Coeffici } \\
\text { ent }\end{array}$ & sig & Result \\
\hline 1 & $\begin{array}{l}\text { Recruitme } \\
\text { nt }\end{array}$ & \multirow[t]{3}{*}{$\begin{array}{l}\text { Performa } \\
\text { nce }\end{array}$} & 0.456 & $\begin{array}{l}0.0 \\
00\end{array}$ & $\begin{array}{l}\text { Significa } \\
\text { nce }\end{array}$ \\
\hline 2 & Selection & & 0.041 & $\begin{array}{l}0.3 \\
18\end{array}$ & $\begin{array}{l}\text { No } \\
\text { significa } \\
\text { nce }\end{array}$ \\
\hline 3 & $\begin{array}{l}\text { Retrench } \\
\text { ment }\end{array}$ & & 0.752 & $\begin{array}{l}0.0 \\
00 \\
\end{array}$ & $\begin{array}{l}\text { Significa } \\
\text { nce }\end{array}$ \\
\hline
\end{tabular}

\section{Discussion}

Hotels are responsible for huge volumes of waste and unnecessary use of water. Hotels often attract adverse resource depletion reactions. The National Tourism Strategy (NTS) (2004-2010) was adopted by Jordan in the year 2004. This is the first comprehensive strategy to enable the tourism sector to increase its sustainable practises capacity. In Jordan, the hotel industry is considered a vital part of the economy, but there has been little research on sustainable practises in environmental and business aspects. Green recruitment and selection have a positive effect on environmental performance, contributing to the important strategy to be integrated into green recruiting for the hotel industry. It offers employers the opportunity to position themselves in front of competitors and it gives them the chance to attract and retain candidates after training and orientation. The second NTS 2011-2015 stressed how the tourism \& hospitality sector would achieve long-term sustainability objectives by considering the three pillars of social, economic and environmental sustainability processes. To improve environmental performance, the hotel industry needs to recruit green candidates. The hotel industry can invest in people who are already environmentally sensitive and used for the management of environmental issues such as waste management, recycling and ISO 14001 certification. A study also showed the positive impact of green compensation on environmental performance. It was suggested that if organisations act in a green HRM, they will benefit from competitiveness such as environmental performances, social well-being and financial success.

\section{Conclusion}

Green HR refers to the contribution of human resource policies and practices towards the broader corporate environmental agenda of sustainable use of natural resources. It is the contribution of people management policies and activities towards the organization's goals. Typical green activities include teleconferencing and virtual interviews, online training, electronic filing, green payroll, company transport, walking or cycling to work; save energy and resources, shutting down laptops; promoting the 3R's reduce, reuse and recycle. There are many benefits of GHRM like improved employee loyalty and brand recognition, increased workforce productivity, efficiency, motivation and employee retention. This research has been conducted to examine the differences in green HR practices of Movenpick hotel and Intercontinental hotel.A sample of 151 employees has been selected for the study. Data have been collected through self-administered questionnaires and analyzed with the application of independent sample t-test. The analysis of the data revealed that significant difference do not exists in green HR practicesin Movenpick hotel and Intercontinental hotel.Therefore, it is suggested to put emphasis on green activities in both the hotels. The employees should be aware about green HRM concept, strategy and initiatives by encouraging conferences, seminar on environmental sustainability. The hotels take disciplinary action for the employees who violate rules of green practices. Moreover, the banks should generate online leave application and electronic slip generation system and uses recycled paper in the office and puts record electronically.

\section{Acknowledgements}

This work has been carried out during the support granted to the author Majed. M. AL_Rawashdeh from Arab University, college of Technology University (AUCT) during the academic year 2020/2021

\section{References}

[1] Ahmed et al (2018).Green work life balance, green human resource management practices on employee satisfaction. The European Proceedings of Social \&Behavioural Sciences, 1223-1231.

[2] Amgad S. D. Khaled, Dr.Avinash Sharma, Fatehi Ali Mohammed Almugari, Dr. Salma Ahmed. (2020). REBUILDING ETAILERS' SERVICES: A STUDY ON DEFEND PURCHASE at Retail Store . International Journal of Advanced Science and Technology, 29(12s), 1664-1674. Retrieved from 
http://sersc.org/journals/index.php/IJAST/ article/view/23904

[3] Amgad S.D. Khaled, Nabil Mohamed Alabsy, Eissa A. Al-Homaidi and Abdulmalek M.M. Saeed (2020). The impact of the COVID-19 pandemic on retailer performance: empirical evidence from India. Innovative Marketing, 16(4), 129-138. doi:10.21511/im.16(4).2020.11

[4] Bangwal, D., \& Tiwari, P. (2015). Green HRM-A way to greening the environment. IOSR Journal of Business and Management (IOSR-JBM), 17(12), 45-53. Retrieved from http://www.iosrjournals.org/ iosr-jbm.html

[5] Bombiak, E. and Kluska, A.N. (2018). Green human resource management as a tool for the sustainable development of enterprises: Polish Young Company Experience. Sustainability 10, 1739; doi:10.3390/su10061739

[6] Cherian, J. \& Jacob, J. (2012). A study of Green HR practices and its effective implementation in the organization: A review. International Journal of Business and Management, 7, 25-33.

[7] D. Khaled, A. S., Ahmed, S., Khan, M. A., Al Homaidi, E. A., \& Mansour, A. M. D. (2021). Exploring the relationship of marketing \& technological innovation on store equity, word of mouth and satisfaction. Cogent Business \& Management, 8(1), 1861752.

[8] Iqbal, J. et al (2016). The effect of green HRM practices on sustainability: evidence from manufacturing companies in Pakistan. Pakistan Journal of Social Sciences (PJSS) Vol. 36, No. 1, 177-188

[9] Jabbar, MH and Abid, M. (2015). A study of green HR practices and its impact on environmental performance: A Review. MAGNT Research Report, Vol.3 (8), 142154.

[10] John, S.F., and Sathiq, P.N. (2018). A study on the influence of green HR practices on employee satisfaction among selected scheduled banks. International Journal of Business and Management
Invention (IJBMI), Vol. 7, Issue 10, Ver. 2, 44-48.

[11] Karande,S. and Bihade,V. (2018). Green HRM practices in corporate sectors for environmental sustainability. International Journal of Innovative Science and Research Technology, Vol.3, Issue 7, 258265.

[12] Khaled, A. S., Ahmed, S., Yahya, A. T., \& Farhan, N. H. (2020). The role of innovation on Indian retail industry. International Journal of Business Innovation and Research, 23(4), 435-452.

[13] Khaled, A. S., Alomari, K. M., AlshakeTheep, I., \& Ahmed, A. M. M. (2020). An Empirical Study of Convenience of Online Services and Purchases. Journal of Computational and Theoretical Nanoscience, 17(9-10), 46274634.

[14] Maimako, L.B. \&Bambalee, A.J. (2016). Human resource management practices and employee satisfaction at Kano state owned universities: a conceptual paper. Journal of Marketing and Management, 7 (2), 1-18.

[15] Mehta, K. \&Chugan, P.K. (2015). Green HRM in pursuit of environmentally sustainable business. Universal Journal of Industrial and Business Management Vol. 3(3), $74-81$

[16] Oyewale, O. (2019). Green human resource management practices (GHRM) and Its effect on sustainable competitive edge in the Nigerian manufacturing industry: a study of Dangote Nigeria Plc. URL: https:// www.google.com/ search?q=A +Dissertation +on+ green thuman +resource +management $+($ GHRM $)+$ practices +and+its +effect +on the +sustainable +competitive +edge + in + the + Nigerian + Manufacturing $+\mathrm{I}$ ndustry

[17] Paille, P.; Chen, C.; Boiral, O.; Jin, J. (2014). The impact of human resource management on environmental performance: An employee-level study. J. Bus. Ethics, 121, 451-466. 
[18] Rahman, M., Ahsan, A., Hossain, M., \&Hoq, M.R. (2013). Green banking prospects in Bangladesh. Asian Business Review, 2(4), 59-63. Retrieved from http://oaji.net/articles/2014/8001398829513.pdf

[19] Reddy, YV (2017). Green HRM Initiatives: practices and strategic implementation within the organization. Abhinav National Monthly Refereed Journal of Research in Commerce \& Management, Volume 6, Issue 11, 62.

[20] Renwick, D. W.S., Redman, T., \& Maguire, S. (2013). Green HumanResource Management: A review and research agenda. International Journal of Management Reviews, Vo1.15, No. 1, $1-14$.

[21] Sarode, AP, Patil, J., and Patil, D.P. (2016). A study of Green HRM and Its Evaluation with Existing HR Practices in Industries within Pune Region. International Journal of Research in Engineering, IT and Social Sciences, Vol. 6, Issue 04, 49-67.

[22] Sayed, S. (2015). Green HRM-A tool of sustainable development, Vol. 5, Issue VI, URL:https://www.worldwidejournals.com/ indian-journal-of-applied-research-(IJAR)/ article

[23] Sharma, R., \& Gupta,N. (2015). Green HRM: An innovative approach to environmental sustainability. Twelfth AIMS International Conference on Management. Retrieved from http:// www.aimsinternational.org/ aims12/12ACD/PDF/K723-final.pdf

[24] Verma, R. (2015). Green HRM Requirement of 21st Century. International Journal of Recent Research in Commerce Economics and Management (IJRRCEM), 2(2), 39-44.

[25] Yusoff, Y.M., et al. (2015). Conceptualization of green human resource management: An exploratory study from Malaysianbased multinational companies. International Journal of Business Management and Economic Research, 6 (3). 